\author{
Piotr Zasępa*
}

\title{
TRENDY TRANSAKCJI IPO I ICH WPEYW NA POZIOM DEZINWESTYCJI FUNDUSZY VENTURE CAPITAL
}

\section{WSTĘP}

Załamanie rynków finansowych i niskie wyceny spółek na rynkach giełdowych spowodowały spadek liczby transakcji pierwotnych ofert publicznych (IPO) zarówno w USA jak i rynkach europejskich. Jednym z głównych beneficjentów rozwoju transakcji IPO na giełdach papierów wartościowych są fundusze venture capital. Ich udział $\mathrm{w}$ realizacji tych transakcji jest dość znaczący i ma znaczny wpływ na poziom inwestycji funduszy w przyszłości. Ponadto spółki zasilane funduszami venture capital stanowią bardzo atrakcyjny cel inwestycyjny, który pozwala osiagnąć ponadprzeciętne stopy zwrotu po transakcji IPO ze względu na niedoszacowanie ich wartości w momencie dezinwestycji. Celem artykułu jest analiza wpływu zmieniających się trendów transakcji IPO na rynek dezinwestycji i inwestycji funduszy venture capital w USA, UE oraz w Polsce w latach 2000-2012.

\section{ROZWÓJ RYNKU PIERWOTNYCH OFERT PUBLICZNYCH W LATACH 2000-2011}

Pierwotna oferta publiczna polega na wprowadzeniu po raz pierwszy walorów spółki do obrotu giełdowego, na skutek czego zmienia się struktura właścicielska jednostki. Transakcja ta jest niezwykle ważna w procesie rozwoju przedsiębiorstw oraz kształtowania się i rozwoju rynku kapitałowego. Daje ona szansę przedsiębiorcy na pozyskanie kapitału na rozwój, obiektywną wycenę oraz umocnienie wizerunku firmy. Tendencje na różnych rynkach światowych w zakresie transakcji IPO miały swoje ważne punkty. Lata 2000-2007 na rynkach finansowych to powolne odbudowywanie pozycji transakcji IPO na gieł-

\footnotetext{
* Dr nauk ekonomicznych, Akademia im. Jana Długosza w Częstochowie.
} 
dach papierów wartościowych po załamaniu się notowań indeksów giełdowych związane z pęknięciem tzw. bańki internetowej. Pierwsze miesiące kryzysu rynków finansowych w latach 2008-2010 odbiły się w sposób znaczący na wycenach spółek notowanych na giełdach, co spowodowało praktycznie brak pierwotnych ofert publicznych na głównych rynkach giełdowych świata. Równolegle z pogarszającą się koniunkturą i możliwościami przeprowadzenia transakcji IPO, fundusze venture capital ograniczyły swoje wyjścia $\mathrm{z}$ inwestycji do niezbędnego minimum. Zostały do tego zmuszone bardzo niską płynnością na rynkach giełdowych oraz niedostatecznym rozwojem swoich spółek portfelowych. Analiza rynku IPO przez fundusze odbija się na poziomach realizacji transakcji dezinwestycji, wśród których pierwotna oferta publiczna ma duży udział. Trendy, jakie można zaobserwować w transakcjach IPO są ściśle powiązane z możliwościami gospodarek narodowych oraz $\mathrm{z}$ poziomami notowań indeksów i wyceną spółek notowanych na giełdach papierów wartościowych. Globalne rynki kapitałowe możemy obecnie podzielić na dwa główne bieguny między którymi dochodzi do silnej konkurencji o kapitał inwestorów. Pierwszą grupę stanowią kraje wysoko rozwinięte z ustabilizowaną gospodarką rynkową (USA, Japonia, Wielka Brytania, Niemcy), druga grupa to tzw. rynki wschodzące wśród których należy wymienić Chiny, Indie, Brazylie, Rosje czy kraje Europy Centralnej.

Analizując notowania głównych indeksów światowych należy stwierdzić, iż lata 2003-2007 to dynamiczny wzrost ich wartości. Lata 2007-2009 to dynamiczny spadek indeksów wynoszący nawet 60\%. Okres 2009-2013 to równie dynamiczny, co spadek wzrost notowań poszczególnych indeksów (w granicach $100 \%$ ). Większość indeksów giełdowych w długim okresie jest ze sobą silnie skorelowanych, dlatego sama analiza wpływu poszczególnych indeksów na transakcje IPO w poszczególnych regionach nie jest konieczna. Wartość światowych transakcji IPO na świecie bardzo dobrze odzwierciedla trendy panujące na rynku giełdowym. Należy również określić rożne fazy cyklu giełdowego i związane $\mathrm{z}$ tym niedoszacowanie lub przeszacowania wartości ofert publicznych, co wiąże się z uzyskiwaną stopa zwrotu z inwestycji w średnim okresie.

Analizując dokładniej dane dotyczące liczby i wartości transakcji IPO można stwierdzić, iż w okresie 2000-2012 nastapiła jej diametralna geograficzna zmiana. Kraje azjatyckie wykorzystując swój dynamiczny rozwój skupiają większość globalnych transakcji IPO. Dużą rolę w kształtowaniu tego trendu miały procesy prywatyzacyjne przeprowadzane przez państwa rozwijające się. W 2006 r. wartość ofert publicznych związanych z prywatyzacjami sięgnęła 105 mld USD. Kwoty te dotyczyły 248 prywatyzacji przeprowadzonych w 48 rozwijających się gospodarkach takich jak: Chiny, Indie, Turcja, Egipt, Polska czy Brazylia ${ }^{1}$.

\footnotetext{
${ }^{1}$ S. Ki ki eri, Privatization trends, World Bank, styczeń 2008.
} 
Wartość oraz liczba IPO na świecie w latach 2000-2012

\begin{tabular}{|c|c|c|}
\hline Rok & Kwota w mld USD & Liczba IPO \\
\hline \hline 2000 & 210 & 1883 \\
\hline 2001 & 94 & 832 \\
\hline 2002 & 66 & 839 \\
\hline 2003 & 50 & 864 \\
\hline 2004 & 124 & 1516 \\
\hline 2005 & 167 & 1537 \\
\hline 2006 & 246 & 1729 \\
\hline 2007 & 287 & 1979 \\
\hline 2008 & 95 & 762 \\
\hline 2009 & 112,4 & 577 \\
\hline 2010 & 284,6 & 1393 \\
\hline 2011 & 169,9 & 1225 \\
\hline $2012 q 3$ & 118 & 768 \\
\hline
\end{tabular}

Źródło: obliczenia własne na podstawie raportów Ernst \& Young Global IPO Trends 2006-2013.

Oczywiście w następnych latach trend wzrostowy ofert prywatyzacyjnych wraz z niskimi notowaniami indeksów giełdowych osłabił się, jednak mimo to w 2008 r. 38 krajów przeprowadziło 196 transakcji na kwotę 38 mld USD. W porównaniu z 2007 r. był to $20 \%$ spadek w ilości transakcji i aż 19 krajów wycofało swoje plany prywatyzacyjne. Transakcje IPO w 2007 r. stanowiły aż $75 \%$ wszystkich transakcji prywatyzacyjnych, gdy w 2008 r. już tylko $40 \%$. Kraje, które generują ponad $80 \%$ wartości wszystkich transakcji prywatyzacyjnych to Chiny, Rosja oraz Turcja ${ }^{2}$. Lata 2009 i 2010 były rekordowymi pod względem dochodów rządów z prywatyzacji, jednak udział transakcji IPO był niewielki i kształtował się na poziomie ok $30 \%^{3}$. Najważniejszym trendem zmian charakteru transakcji IPO jest to, iż w 2000 r. głównym odbiorcą kapitału był rynek UE oraz rynek USA. W 2011 r. i 2012 r. głównym odbiorcą kapitałów IPO był rynek azjatycki. Sam rynek CHRL zanotował 42\% udział w wartościach transakcji IPO i 31,7\% udział w liczbie transakcji. Drugim rynkiem w $2011 \mathrm{r}$. były USA z udziałem $21,2 \%$. W 2012 r. rynek azjatycki zanotował $76 \%$ udział w wartości transakcji IPO, USA $15 \%$ a UE jedynie 5\%. Nastapiła istotna zmiana i przesunięcie wagi poszczególnych regionów w okresie 2000-2012 jeśli chodzi o wartość transakcji IPO. Na początku dekady USA oraz Europa generowały

\footnotetext{
${ }^{2}$ S. Ki ki e ri, Privatization trends, World Bank, maj 2010.

${ }^{3}$ W. Me g g i s i o n, Privatization trends and major deals 2010, The 2010 PB Report, s. 15.
} 
ponad $75 \%$ wartości wszystkich debiutów, gdy w roku 2012 to już tylko $20 \%$. Ich miejsce zajęły państwa Azji, która wraz z Ameryką Południową pokrywa $80 \%$ globalnego napływu kapitału związanego z ofertą publiczną. Należy również zaznaczyć, iż w wymienionych regionach wartość IPO wzrasta szybciej niż ich liczba. Niestety tendencja ta odbija się na sytuacji finansowej funduszy VC, które tracą możliwość szybkiego i pewnego źródła środków finansowych jakim jest rynek kapitałowy.

\section{UDZIAL FUNDUSZY VENTURE CAPITAL/PRIVATE EQUITY W TRANSAKCJACH IPO NA RYNKU USA ORAZ UE}

Zdobycie środków finansowych, rozwój spółki portfelowej i dezinwestycja to standardowy proces inwestycyjny funduszy wysokiego ryzyka. Bardzo dużym beneficjentem rozwoju rynków kapitałowych są małe i średnie przedsiębiorstwa zasilane kapitałami funduszy venture capital oraz private equity. Silna korelacja rynku IPO oraz inwestycji venture capital w zdecydowany sposób wpływa na kondycję funduszy i osiaganą przez nich stopę zwrotu. Proces dezinwestycji jest dla nich niezmiernie ważny, ze względu na możliwość sprzedaży swoich akcji przedsiębiorstwa udziałowego. Jest to niezbędny proces umożliwiający uzyskanie płynności przez fundusz celem reinwestycji środków oraz dający szansę na osiagnięcie ponadprzeciętnej stopy zwrotu w momencie dogodnego momentu sprzedaży udziałów. Osiaggnięte stopy zwrotu pozwalają na wzrost zainteresowania inwestorów tym segmentem rynku finansowego i określają możliwości jego dalszego rozwoju. Niestety nie tylko wartość wewnętrzna spółki wpływa na powodzenie IPO. Ma na to wpływ również wielkość spółki, płynność oraz stan rynku kapitałowego. Na wyniki funduszy wpływają również zachowania się notowań indeksów giełdowych związane z wyceną spółek giełdowych, co może wpływać na przeszacowanie lub niedoszacowanie wartości IPO. Należy stwierdzić również, iż na wycenę spółek w procesie IPO wpływa pozycja emitenta. Jeśli oferentem jest fundusz VC lub PE rynek niedoszacowuje wartość emisji w stosunku do podobnych spółek niezasilanych VC. Dodatkowo na poziom wyceny wpływa doświadczenie oraz reputacja funduszu VC oceniana przez inwestorów ${ }^{4}$. Na ocenę funduszu i prawidłowe przeprowadzenie transakcji IPO może również mieć wpływ długa historia operacyjna funduszu, doświadczenie międzynarodowe, poziom udziałów jakie posiada oraz sposób marketingu ${ }^{5}$. Moment dezinwestycji jest więc niezmiernie ważny w procesie kształtowania stóp zwrotu funduszu VC. Rola funduszy VC w procesie rozwoju transakcji IPO na rynkach

${ }^{4}$ J. G. Macintosh, D. Cumming, Venture capital exits in Canada and the United States, „University of Toronto Law Journal”, s. 185.

5 A. P a bi a n (red.), Zarzqdzanie działalnościq marketingowa $w$ skali krajowej, międzynarodowej i globalnej, Wydawnictwo Politechniki Częstochowskiej, Częstochowa 2011, s. 6. 
kapitałowych była rozważana przez wielu naukowców. Większość prac dotyczyła niedoszacowania wyceny spółek oferowanych przez fundusze. Pierwsze z prac wskazywały jednak na przeszacowanie wartości tych spółek i były przedstawione w 1991 r. przez W. Meginsona i K. Weiss ${ }^{6}$ związane z tzw. certyfikacją funduszu wyjaśnianą wyższą reputacją i doświadczeniem. Kolejne opracowania wskazywały już na niedoszacowanie ofert funduszy. Pierwsze tego typu opracowanie przedstawił w 2004 r. P. Lee i S. Wahal badając okres 1980$2000^{7}$. Dalsze prace wskazują na inne niż przeszacowanie i niedoszacowanie sposoby określania wpływu funduszu VC na dalszy proces rozwoju spółek. Różnice w przeszacowaniu i niedoszacowaniu spółek zasilanych VC i bez udziału kapitałów zewnętrznych znikają $\mathrm{w}$ rok od momentu $\mathrm{IPO}^{8}$. Należy wskazać, iż w 2000 r. w czasie tzw. boomu spółek internetowych niedoszacowanie wartości spółek na rynku amerykańskim w procesie IPO wynosiło aż $65 \%{ }^{9}$. Ponadto po tym okresie pozostała opinia, iż nierozwinięte przedsiębiorstwo o złej jakości może w okresie baniek spekulacyjnych wejść na giełdę, co znacznie obniżyło poziom zaufania do oferujących technologiczne spółki funduszy venture capital. Następstwem tego było wdrożenie bardziej rygorystycznych przepisów dotyczących spółek przeprowadzających proces IPO, co znacznie zmieniło podejście funduszy $\mathrm{VC}$ do tego sposobu dezinwestycji.

Analizując dane dotyczące pozyskiwanych kapitałów oraz inwestycji dokonywanych przez fundusze VC oraz PE należy stwierdzić, iż okres ich dynamicznego wzrostu przypada na lata 2002-2008. Rok 2009 to chwilowe załamanie inwestycji VC spowodowane kryzysem finansowym. Lata 2010-2012 to powolny wzrost inwestycji na rynkach globalnych. Na wybranych rynkach UE inwestycje kształtowały się w korelacji z globalnymi inwestycjami z możliwym opóźnieniem jednego roku. Rynek polski charakteryzuje się wysoką dynamiką inwestycji funduszy podwyższonego ryzyka po niewielkim załamaniu inwestycji w $2002 \mathrm{r}$.

Sposoby dezinwestycji funduszu mogą przybierać różną formę. Dwoma najważniejszymi sposobami zakończenia inwestycji są sprzedaż udziałów inwestorowi strategicznemu (ang. trade sales) oraz IPO ${ }^{10}$. Jak już zostało wskazane, trendy na rynkach kapitałowych w zakresie transakcji IPO w znaczny sposób wpływają na wychodzenie przez fundusze ze swoich inwestycji za pomocą giełdy. Załamanie na rynku transakcji IPO w USA oraz na giełdach europejskich

\footnotetext{
${ }^{6}$ W. Me g g in s o n, K. W e is s, Venture capital certification in Initial Public Offering, „The Journal Of Finance", July 1991, Vol. XLVI, No. 3, s. 879-892.

${ }^{7} \mathrm{P}$. Lee, S. W a ha l, Grandstanding, Certification and the underpricing of venture capital backed IPO, ,Journal of Financial Economics” 2004, Vol. 73, s. 375-407.

${ }^{8} \mathrm{~T}$. Chemmanur, E. Lotskina, The role of venture capital backing in initial public offering, Boston Colage, February 2005, s. 38.

9 J. R. Ritt e r, I. W e $1 \mathrm{ch}$, A review of IPO Activity, pricing, and allocation, ,Journal of Finance" 2002, Vol. 57(4), American Finance Association, s. 1795-1828.

${ }^{10}$ P. Z a s e p a, Venture Capital - sposoby deinzwestycji, CEDEWU, Warszawa 2010, s. 150.
} 
wpłynęło na zmianę tendencji sposobów dezinwestycji przeprowadzanych przez fundusze VC. Transakcja sprzedaży inwestorowi strategicznemu zaczęła dominować wśród sposobów zakończenia inwestycji, a fundusze poszukują swoich klientów wśród dużych korporacji. Kryzys transakcji IPO może być związany z nowymi, wymagającymi regulacjami, konfliktami, upadkiem niektórych banków inwestycyjnych oraz wzrostem zainteresowania mniej skoncentrowanymi i wymagającymi rynkami azjatyckimi. Należy wskazać, iż dla okresu 1975-2010 aż 79,9\% spółek w USA zasilanych VC dokonało IPO w pierwszych 10 latach funkcjonowania a odsetek spółek niezasilanych środkami VC wyniósł jedynie $37,2 \%$. Dla okresu 5 letniego było to odpowiednio $52,2 \%$ oraz $17,4 \%{ }^{11}$.

Tabela 2

Udział dezinwestycji funduszy venture capital w transakcjach IPO na rynku USA

\begin{tabular}{|c|c|c|c|c|c|c|}
\hline Rok & $\begin{array}{c}\text { Liczba IPO } \\
\text { VC }\end{array}$ & $\begin{array}{c}\text { Liczba IPO } \\
\text { ogółem }\end{array}$ & $\begin{array}{c}\text { Udział } \\
\text { w \% }\end{array}$ & $\begin{array}{c}\text { Wartość } \\
\text { IPO VC } \\
\text { w mld USD }\end{array}$ & $\begin{array}{c}\text { Wartość } \\
\text { IPO ogółem } \\
\text { w mld USD }\end{array}$ & $\begin{array}{c}\text { Udział } \\
\text { w \% }\end{array}$ \\
\hline \hline 2000 & 242 & 446 & $54,26 \%$ & 25,4 & 108,2 & 23,48 \\
\hline 2001 & 37 & 85 & $43,53 \%$ & 3,4 & 41,3 & 8,23 \\
\hline 2002 & 22 & 81 & $27,16 \%$ & 2,4 & 25,4 & 9,45 \\
\hline 2003 & 29 & 60 & $48,33 \%$ & 2,1 & 15,2 & 13,82 \\
\hline 2004 & 94 & 286 & $32,87 \%$ & 11,1 & 39 & 28,46 \\
\hline 2005 & 57 & 285 & $20,00 \%$ & 4,4 & 31,4 & 14,01 \\
\hline 2006 & 57 & 187 & $30,48 \%$ & 5,3 & 40,4 & 13,12 \\
\hline 2007 & 86 & 172 & $50,00 \%$ & 10,32 & 46,4 & 22,24 \\
\hline 2008 & 6 & 31 & $19,35 \%$ & 0,47 & 24,1 & 1.92 \\
\hline 2009 & 8 & 12 & $66,67 \%$ & 1,642 & 19,2 & 8,55 \\
\hline 2010 & 9 & 52 & $17,31 \%$ & 7,6 & 36,3 & 20,93 \\
\hline 2011 & 51 & 67 & $76,12 \%$ & 9,8 & 26,4 & 37,12 \\
\hline 2012 & 49 & 60 & $81,67 \%$ & 21,4 & 42,6 & 50,02 \\
\hline
\end{tabular}

Źródło: NVCA Yearbooks 2010-2012 oraz PWC IPO Trends 2012.

Analizując dane zawarte w tab. 2 należy stwierdzić, iż udział funduszy VC w transakcjach IPO w USA zarówno ilościowy, jak i wartościowy jest bardzo wysoki. Rynek kapitałowy w USA to główne źródło pozyskiwania kapitałów przez rozwijające się przedsiębiorstwa. Dla funduszy VC jest to również bardzo ważne źródło kapitałów i stan rynku kapitałowego w zdecydowany sposób wpływa na poziom IPO funduszy VC. Fakt, iż jest to ważne źródło kapitału

${ }^{11}$ A. Gi11, U. Waltz, Going public - going private. A case of VC-backed firms, Goethe University 2012, s. 2. 
wskazuje jak wysokie udziały generują fundusze VC w okresach bessy na rynkach giełdowych, które dochodzą do poziomów 76\% i $81 \%$ dla liczby IPO oraz $37 \%$ i $50 \%$ dla wartości IPO w latach 2011 i 2012. Sa to niespotykane poziomy od 2000 r. co świadczy o dużym uzależnieniu funduszy VC od wykorzystywania IPO jako sposobu dezinwestycji mimo znacznego spadku w stosunku do lat 2004-2007. Liczba 60 IPO w 2012 r. jest niższa niż zanotowana na rynku hinduskim (63) i dużo niższa niż liczba IPO w Chinach (295).

Rynek europejski jest odmienny niż rynek funduszy VC w USA. Wpływa na to charakter gospodarki i oparcie rozwoju przedsiębiorstw o finansowanie kapitałem obcym oraz niższa awersja do ryzyka. Wpływa to na charakter inwestycji funduszy i dominację rynku PE nad rynkiem VC. Zachowanie rynku IPO oraz funduszy VC i PE na tym rynku opisuje tab. 3.

Tabela 3

Udział dezinwestycji venture capital $\mathrm{w}$ transakcjach IPO na rynku europejskim

\begin{tabular}{|c|c|c|c|c|c|c|}
\hline Rok & $\begin{array}{c}\text { Liczba IPO } \\
\text { VC }\end{array}$ & $\begin{array}{c}\text { Liczba IPO } \\
\text { ogółem }\end{array}$ & $\begin{array}{c}\text { Udział } \\
\text { w } \%\end{array}$ & $\begin{array}{c}\text { Wartość } \\
\text { IPO VC/PE } \\
\text { w mld EUR }\end{array}$ & $\begin{array}{c}\text { Wartość } \\
\text { IPO ogółem } \\
\text { w mld EUR }\end{array}$ & $\begin{array}{c}\text { Udział } \\
\text { w \% }\end{array}$ \\
\hline \hline 2000 & 120 & 480 & $25,00 \%$ & 1,28 & 50,5 & $2,53 \%$ \\
\hline 2001 & 26 & 380 & $6,84 \%$ & 1,39 & 25,5 & $5,45 \%$ \\
\hline 2002 & 30 & 141 & $21,28 \%$ & 1,26 & 16,3 & $7,73 \%$ \\
\hline 2003 & 37 & 103 & $35,92 \%$ & 1,6 & 6,7 & $23,88 \%$ \\
\hline 2004 & 59 & 420 & $14,05 \%$ & 2,3 & 19,7 & $11,68 \%$ \\
\hline 2005 & 184 & 598 & $30,77 \%$ & 2,65 & 51,4 & $5,16 \%$ \\
\hline 2006 & 108 & 806 & $13,40 \%$ & 3 & 65,2 & $4,60 \%$ \\
\hline 2007 & 199 & 771 & $25,81 \%$ & 2,69 & 64,3 & $4,18 \%$ \\
\hline 2008 & 72 & 295 & $24,41 \%$ & 0,71 & 9,9 & $7,17 \%$ \\
\hline 2009 & 109 & 126 & $86,51 \%$ & 1,24 & 6,2 & $20,00 \%$ \\
\hline 2010 & 155 & 380 & $40,79 \%$ & 2,09 & 26 & $8,04 \%$ \\
\hline 2011 & 118 & 430 & $27,44 \%$ & 3,5 & 26 & $13,46 \%$ \\
\hline
\end{tabular}

Źródło: EVCA Yearbooks 2000-2012, IPO Watch Europe 2003-2012.

Udział funduszy w transakcjach IPO na rynku europejskim nie jest już tak znaczny jak w przypadku USA, ale utrzymuje się na stabilnym i wysokim poziomie. Rynek europejskich nie jest jednolity, jest rynkiem rozdrobnionym, na którym funkcjonuje wiele różnych giełd papierów wartościowych. Brak jednego głównego rynku sprawia, iż możliwości dezinwestycji za pomocą IPO są ograniczone, gdyż nie wszystkie giełdy charakteryzuje wystarczająca płynność. Giełdą skupiającą najwięcej transakcji IPO przeprowadzanych przez fundusze VC jest giełda w Londynie, która w zależności od okresu notuje około 40-50\% udział. 
Wśród giełd europejskich wyróżnia się również GPW w Warszawie, która w latach 2007-2011 odnotowała duży wzrost liczby i wartości transakcji IPO. Było to spowodowane otwarciem rynku NewConnect, na którym plasuje się duża liczba emisji w porównaniu z głównym parkietem giełdy warszawskiej.

Tabela 4

Udział dezinwestycji venture capital $\mathrm{w}$ transakcjach IPO na rynku polskim

\begin{tabular}{|c|c|c|c|c|c|c|}
\hline Rok & $\begin{array}{c}\text { Liczba IPO } \\
\text { VC }\end{array}$ & $\begin{array}{c}\text { Liczba IPO } \\
\text { ogółem }\end{array}$ & $\begin{array}{c}\text { Udział } \\
\text { w \% }\end{array}$ & $\begin{array}{c}\text { Wartość } \\
\text { IPO VC/PE } \\
\text { w mld PLN }\end{array}$ & $\begin{array}{c}\text { Wartość } \\
\text { IPO ogółem } \\
\text { w mld PLN }\end{array}$ & $\begin{array}{c}\text { Udział } \\
\text { w \% }\end{array}$ \\
\hline \hline 2000 & 1 & 14 & $7,14 \%$ & 0,02226 & 9,1 & $0,24 \%$ \\
\hline 2001 & 7 & 9 & $77,78 \%$ & 0,126 & 1,1 & $11,45 \%$ \\
\hline 2002 & 3 & 6 & $50,00 \%$ & 0,254 & 0,6 & $42,33 \%$ \\
\hline 2003 & 9 & 36 & $25,00 \%$ & 0,992 & 2,9 & $34,21 \%$ \\
\hline 2004 & 9 & 36 & $25,00 \%$ & 1,0038 & 3,7 & $27,13 \%$ \\
\hline 2005 & 15 & 35 & $42,86 \%$ & 0,9198 & 5,2 & $17,69 \%$ \\
\hline 2006 & 21 & 38 & $55,26 \%$ & 3,1416 & 4,1 & $76,62 \%$ \\
\hline 2007 & 6 & 105 & $5,71 \%$ & 0,231 & 18,2 & $1,27 \%$ \\
\hline 2008 & 1 & 94 & $1,06 \%$ & 0,0084 & 12,3 & $0,07 \%$ \\
\hline 2009 & 4 & 39 & $10,26 \%$ & 0,5964 & 6,9 & $8,64 \%$ \\
\hline 2010 & 2 & 60 & $3,33 \%$ & 0,21 & 15,5 & $1,35 \%$ \\
\hline 2011 & 5 & 210 & $2,38 \%$ & 1,512 & 9,2 & $16,43 \%$ \\
\hline
\end{tabular}

Źródło: GPW, EVCA Yearbook 2000-2012.

Analizując dane IPO funduszy VC oraz PE w Polsce należy stwierdzić, iż ich udział w liczbie dokonywanych transakcji w okresie 2000-2006 był wysoki i kształtował się na poziomie powyżej $25 \%$. Udziały wartościowe notowały nieznacznie niższe poziomy, co w niektórych przypadkach może oznaczać, iż polskie fundusze dość szybko podejmują decyzję o IPO i wartość spółek nie była wysoka w momencie wejścia na giełdę. Być może fundusze posiadały pewne blokady (lock up) związane ze sprzedażą akcji i liczyły na wzrost ich wartości po dokonaniu transakcji IPO. Lata 2007-2011 to spadek udziału transakcji IPO dokonywanych przez fundusze w ogólnej liczbie transakcji na GPW. W przypadku rynku polskiego uruchomienie rynku NewConnect prawdopodobnie zmniejszyło liczbę transakcji IPO przeprowadzanych przez fundusze, gdyż przedsiębiorstwa traktują nowy segment rynku jako alternatywę dla pozyskania finansowania ze strony funduszy VC oraz PE. 
Udział poszczególnych rodzajów dezinwestycji dokonywanych przez fundusze w Polsce w latach 2007-2011 w \%

\begin{tabular}{|l|c|c|c|c|c|}
\hline \multicolumn{1}{|c|}{ Sposób dezinwestycji } & 2007 & 2008 & 2009 & 2010 & 2011 \\
\hline \hline Sprzedaż inwestorowi strategicznemu & 17,6 & 24,0 & 19,9 & 9,5 & 69,2 \\
\hline IPO & 3,5 & 0,4 & 45,4 & 0,8 & 20,3 \\
\hline Likwidacja & 0,0 & 3,0 & 0,0 & 47,0 & 0,0 \\
\hline Spłata udziałów & 0,0 & 20,9 & 0,0 & 0,0 & 0,0 \\
\hline Spłata pożyczki & 14,0 & 0,0 & 0,0 & 0,0 & 0,2 \\
\hline Sprzedaż innemu funduszowi & 49,8 & 39,0 & 1,9 & 17,1 & 2,3 \\
\hline Sprzedaż instytucji finansowej & 1,6 & 0,0 & 31,7 & 0,2 & 5,8 \\
\hline Sprzedaż zarządowi & 2,4 & 5,2 & 0,0 & 25,4 & 2,0 \\
\hline Inne & 11,2 & 7,4 & 1,1 & 0,0 & 0,2 \\
\hline Razem & 100,0 & 100,0 & 100,0 & 100,0 & 100,0 \\
\hline
\end{tabular}

Źródło: EVCA Yearbook 2012.

Ponadto, tak jak w przypadku światowych tendencji, sprzedaż inwestorowi strategicznemu oraz wykupy menedżerskie stają się jedną z głównych form dezinwestycji. Dodatkowo na podstawie danych dezinwestycji polskich funduszy w ostatnich pięciu latach nie można stwierdzić stabilnej tendencji rozwojowej udziałów poszczególnych kategorii, gdyż każdy ze sposobów dominuje w każdym z różnych okresów. Polski rynek funduszy jest w tym zakresie dość niestabilny, co związane jest ze zmieniającymi się przepisami podatkowymi.

\section{ZAKOŃCZENIE}

Rynek IPO jest bardzo ważnym wyznacznikiem dla realizacji inwestycji przez fundusze venture capital. Możliwość wyjścia za pomocą giełdy papierów wartościowych wydaje się najlepszym i najefektywniejszym sposobem zakończenia inwestycji. Dlatego ważna dla funduszy staje się potrzeba analizy trendów zmian na rynku transakcji IPO i zmiana ich charakteru. Ponadto dane empiryczne wskazują na pozytywne zachowanie się notowanych spółek oferowanych przez fundusze venture capital $\mathrm{w}$ okresie pierwszego roku od przeprowadzenia IPO. Dodatkowo stwierdzono, iż w okresie kolejnych dwóch lat generują jeszcze one pozytywne stopy zwrotu. Są to wiec atrakcyjne spółki i trendy kształtujące poszczególne rynki w znaczny sposób wpływają na możliwości dokonywania tego typu dezinwestycji przez fundusze $\mathrm{VC}$ oraz $\mathrm{PE}$. Znamienny również wydaje się poszukiwanie przez europejskie i amerykańskie spółki kapitałów w Azji 
i odwrotnie, dlatego rynek IPO należy obecnie badać globalnie, gdyż dzięki liberalizacji przepływów kapitałowych granice geograficzne tracą na znaczeniu.

\section{BIBLIOGRAFIA}

Che m manur T., Lotskina E., The role of venture capital backing in initial public offering, Boston Colage, February 2005.

Gill A., Walt z U., Going public - going private. A case of VC-backed firms, Goethe University 2012.

K i k i e r i S., Privatization trends, World Bank, styczeń 2008.

Ki ki eri S., Privatization trends, World Bank, maj 2010.

Le e P., W a hal S., Grandstanding, Certification and the underpricing of venture capital backed IPO, „Journal of Financial Economics” 2004, Vol. 73.

MacIntosh J. G., Cumming D., Venture capital exits in Canada and the United States, „University of Toronto Law Journal”.

Megginson W., Weiss K., Venture capital certification in Initial Public Offering, „The Journal of Finance", July 1991, Vol. XLVI, No. 3.

Meg g i si on W., Privatization trends and major deals 2010, The 2010 PB Report.

$\mathrm{Pabi}$ a $\mathrm{A}$. (red.), Zarzqdzanie działalnościa marketingowa $w$ skali krajowej, międzynarodowej i globalnej, Wydawnictwo Politechniki Częstochowskiej, Częstochowa 2011.

Ritte r J. R., Welch I., A review of IPO Activity, pricing, and allocation, ,Journal of Finance” 2002, Vol. 57(4), American Finance Association.

Z a s e p a P., Venture Capital - sposoby dezinwestycji, CEDEWU, Warszawa 2010.

Piotr Zasępa

\section{IPOS TRENDS AND THEIR IMPACT ON THE LEVEL OF VENTURE CAPITAL DIVESTMENTS}

This paper examine nature of venture capital activity on IPO markets. It is determine that between main IPO markets we see differences in IPO trends and venture capital activity. Period between 2000-2012 shows how divestments of venture capital change accordingly to capital market behaviour. Changing share of venture capital stake in IPO transaction is quite important for their functioning. This paper shows the changes in field of IPO transaction conducted on US, UE and Polish market.

Key words: venture capital, IPO trends. 